\title{
Rethinking Sustained Competitive Advantage from Human Capital
}

\author{
Benjamin Campbell \\ The Ohio State University \\ Russell Coff \\ University of Wisconsin-Madison \\ David Kryscynski \\ Brigham Young University, dk@byu.edu
}

Follow this and additional works at: https://scholarsarchive.byu.edu/facpub

Part of the Management Information Systems Commons

\section{Original Publication Citation}

Campbell, B., Coff, R. \& Kryscynski, D., 2012. Re-thinking Sustained Competitive Advantage from Human Capital. Academy of Management Review. 37 (3): 376-395.

\section{BYU ScholarsArchive Citation}

Campbell, Benjamin; Coff, Russell; and Kryscynski, David, "Rethinking Sustained Competitive Advantage from Human Capital" (2012). Faculty Publications. 1977.

https://scholarsarchive.byu.edu/facpub/1977

This Peer-Reviewed Article is brought to you for free and open access by BYU ScholarsArchive. It has been accepted for inclusion in Faculty Publications by an authorized administrator of BYU ScholarsArchive. For more information, please contact ellen_amatangelo@byu.edu. 


\title{
Rethinking Sustained Competitive Advantage from Human Capital*
}

\author{
Benjamin Campbell** \\ The Ohio State University \\ 744 Fisher Hall \\ 2100 Neil Avenue \\ Columbus, OH 43210 \\ Phone: (614) 292-1747 \\ Email: campbell@fisher.osu.edu \\ Russell Coff \\ University of Wisconsin-Madison \\ 4259 Grainger Hall \\ 975 University Avenue \\ Madison, WI 53706 \\ Phone: (608) 263-6437 \\ Email: RCoff@bus.wisc.edu \\ David Kryscynski \\ Brigham Young University \\ 567 TNRB \\ Provo, UT 84606 \\ Phone: (801) 422-6829 \\ Email:dk@byu.edu
}

January 2012

Forthcoming at The Academy of Management Review

* The authors are grateful for comments and suggestions from Nick Argyres, Jay Barney, Chip Hunter, Joe Mahoney, Shad Morris, Charlie Trevor, Todd Zenger, Heli Wang, Janice Molloy, Clint Chadwick, and seminar participants at the Atlanta Competitive Advantage Conference, the Ohio State University, and the University of Tennessee.

**The authors are equal contributors to this paper and are listed in alphabetical order for convenience. 


\title{
Rethinking Sustained Competitive Advantage from Human Capital
}

\begin{abstract}
The strategy literature often emphasizes firm-specific human capital as a source of competitive advantage based on the assumption that it constrains employee mobility. This paper first identifies three boundary conditions that limit the applicability of this logic. It then offers a more comprehensive framework of human capital-based advantage that explores both demand- and supply-side mobility constraints. The critical insight is that these mobility constraints have more explanatory power than the firm-specificity of human capital.
\end{abstract}




\section{RETHINKING SUSTAINED COMPETITIVE ADVANTAGE FROM \\ HUMAN CAPITAL}

Extant strategy theory suggests that human capital can be a source of sustainable competitive advantage (Coff, 1997; Hall, 1993), but only if isolating mechanisms prevent workers from taking their valuable knowledge and skills to rival firms (Barney, 1991; Rumelt, 1984). One of the most important isolating mechanisms is firm-specific human capital, or knowledge and skills embodied in individuals that cannot be easily applied in other firms (Buchholtz, Ribbens, \& Houle, 2003; Hatch \& Dyer, 2004; Kor \& Leblebici, 2005). Building on Becker’s (1964) seminal work, the prototypical logic in the strategy literature argues that firm-specific human capital limits individuals' mobility while general human capital does not. Thus, firm-specific human capital is assumed to support sustained competitive advantage. Likewise, general human capital is assumed not to support sustained advantages since mobility threats allow workers to appropriate the rents associated with their skills and thereby erode any advantages.

This paper extends theories of human capital-based competitive advantage in two ways. We begin by clarifying three key unstated boundary conditions that limit the usefulness of extant theories connecting human capital and competitive advantage. The following three conditions

must be in place for traditional logics to hold: (1) the exchange value (i.e., market value) of workers' general human capital can be no greater than the use value (i.e., the value created in its current application) of workers' full portfolios of human capital in the focal firm, (2) the exchange value of worker skills and the firm-specificity of those skills must be tightly coupled, and (3) supply-side mobility constraints (i.e., factors that cause workers to choose to stay apart from demand for their skills) cannot be so low that workers are willing to incur substantial financial costs to move. 
Put simply, extant theory suggests homogeneous complementary resources across firms and a strong form of labor market efficiency. Thus, our discussion of boundary conditions highlights the need for a more robust framework connecting human capital and competitive advantage.

Accordingly, after articulating the boundary conditions, the paper contributes by developing a more comprehensive framework predicting when human capital may lead to sustained advantages. We focus on the interaction of both demand- and supply-side constraints on worker mobility, where demand-side constraints affect labor market demand for workers and supply-side constraints influence workers' willingness to supply their labor externally. This differs from the extant strategy literature that has focused primarily on demand-side factors. The framework captures the rich variation in outcomes for real firms and, contrary to the received strategy literature, suggests that, under certain conditions, even general human capital can support a sustained competitive advantage. Thus, we contribute to the growing focus on micro-foundations of competitive advantage by unpacking firm specificity from other reasons why human capital may facilitate sustained performance differences (Felin \& Hesterly, 2007; Foss, 2011).

\section{HOW FIRM-SPECIFIC HUMAN CAPITAL FUNCTIONS AS AN ISOLATING \\ MECHANISM}

A firm has a competitive advantage "if it is able to create more economic value than the marginal (breakeven) competitor” (Peteraf \& Barney, 2003: 314), and firms are positioned to sustain such advantages when isolating mechanisms hinder rivals from acquiring key resources (Rumelt, 1984). Thus, ex-post mobility limits on resources such as non-tradability, switching costs, co-specialization of assets, and high transaction costs play a critical role (Peteraf, 1993). Firmspecificity is one potential isolating mechanism since firm-specific resources cannot be redeployed in other organizations "without sacrifice of productive value" (Williamson, 1988: 70). Hence, 
firm-specific resources have been closely tied to the theory of competitive advantage as a driver of distinctive capabilities (Amit \& Schoemaker, 1993; Conner, 1991). ${ }^{1}$ For example, firms may develop idiosyncratic routines that help them address firm-specific challenges, such as the systems underlying Walmart's hub-and-spoke distribution system to efficiently stock its rural stores. These routines were co-specialized to its rural locations, and Kmart could not easily imitate them without a costly investment in a rural store network.

Firm-specific human capital refers to worker-level knowledge, skills, and abilities (hereafter skills) that have limited applicability outside of the focal firm (Becker, 1964). In contrast, general human capital refers to worker skills that are broadly applicable outside of the focal firm. ${ }^{2}$ Examples of firm-specific human capital include knowledge of a firm's proprietary technology or social landscape. Workers may be able to take such knowledge with them when they leave, but it is imperfectly deployable in the new firm (He \& Wang, 2009; Wang, He, \& Mahoney, 2009). Returning to the example above, Walmart employees who understand the unique distribution systems cannot easily apply this knowledge if they change jobs to rivals since their knowledge is co-specialized to a broad mix of assets unique to Walmart. In contrast, the most common examples of general human capital are the skills gained through education, where basic reading, writing, and math skills are easily deployable in many firms.

Many strategy scholars have suggested that resources and capabilities may take the form of knowledge and skills that are embedded in people (e.g., Coff, 1997; Hatch \& Dyer, 2004; Kor \& Leblebici, 2005). As such, human capital can be at the core of a resource-based advantage if it is

\footnotetext{
${ }^{1}$ This underscores the role of non-substitutability in assuring that rivals lack strategically equivalent resources (Barney, 1991).

${ }^{2}$ In the strategy context, industry-specific (Neal, 1995; Parent, 2000), occupation-specific (Kambourov \& Manovskii, 2009), and task-specific (Gathmann \& Schönberg, 2010) human capital can be treated as special cases of general human capital. These other types of human capital are applicable in other contexts and thus their role in supporting sustained competitive advantage is analogous to that of general human capital.
} 
valuable, rare, and can be kept from rivals. ${ }^{3}$ However, human capital is not owned, or even fully controlled, by the firm. Employees are free to quit at will and take their human capital to alternative employers. As a consequence, human capital can be isolated only to the extent that employees have little ability (or willingness) to leave the firm - i.e., when there are strong ex-post limits to worker mobility (Peteraf, 1993).

The importance of limiting employee mobility in supporting competitive advantage has led strategy scholars to emphasize firm-specific human capital (Helfat, 1994; Kor \& Leblebici, 2005; Wang et al., 2009). ${ }^{4}$ This emphasis is due to the deeply held assumption in the classic human capital literature that firm-specific human capital constrains worker mobility (e.g., Bartel \& Borjas, 1977; Glick \& Feuer, 1984; Hashimoto, 1981; Jovanovic, 1979; Parsons, 1972). The logic underlying this assumption is as follows. Firm-specific skills have limited applicability to other firms, resulting in a large difference between the use value of workers' firm-specific skills in the focal firm and the use value of these skills in alternative employers. The low use value affects the wages that alternative firms are willing to pay for these skills in the labor market; thus, these skills have low exchange value. Similarly, because general human capital is broadly applicable, it has high use value to multiple firms, and thus it has high exchange value.

The assumed low exchange value of firm-specific human capital in the labor market creates a dilemma for workers. According to Becker's (1964) investment framework, workers can choose to invest in either firm-specific or general skills - these are mutually exclusive activities. Thus, firm-specific skills represent foregone investments in general skills. By investing in firm-specific

\footnotetext{
${ }^{3}$ We focus, throughout this article, on human capital that is both rare and valuable such that it can be a source of above normal value creation. Human capital that is neither rare nor valuable is not examined here.

${ }^{4}$ While strategy scholars typically assume that general human capital cannot be a source of competitive advantage, strategic human resource management scholars have acknowledged that general skills may, in fact, lead to firm-level performance. An important aspect of firm heterogeneity in their abilities to attract and retain such workers is their human resource practices and systems that may hold workers in place regardless of specificity (e.g. Lepak \& Snell, 1999; Wright, McMahan, \& McWilliams, 1994). We discuss this point more explicitly later.
} 
skills, workers increase their use value to their employers, without accompanying increases in their exchange value in the labor market. If the focal firm pays workers a portion of their increased use value from firm-specific human capital (Becker, 1964; Williamson, 1975), then workers face a dilemma when considering a move. External employers can offer compensation that reflects the exchange value of workers' human capital, but the focal firm can offer compensation up to the use value of their human capital (both firm-specific and general). If general human capital has a constant value across firms (as is often assumed) but firm-specific human capital has a higher value at the current employer, a move requires sacrificing both the compensation for firm-specific skills and the opportunity costs (e.g., of investments in general human capital they could have made). The logical conclusion is that firms can retain workers with firm-specific human capital for less than the full use value. This has led to the deeply held assumption that firm-specific human capital hinders worker mobility (Hashimoto, 1981; Jovanovic, 1979; Parsons, 1972). However, such skills do not necessarily prevent mobility - it is assumed that workers may move if they are willing to accept reduced wages.

From a strategic perspective, firm-specific human capital potentially functions as an isolating mechanism in two ways. First, workers with firm-specific human capital are less likely to leave voluntarily and, therefore, they are less likely to take valuable general knowledge and capabilities to rival firms. Second, even when these workers do leave voluntarily, the firm-specific human capital they take with them cannot be perfectly deployed and utilized in rival firms. In other words, relying on firm-specific human capital enhances a firm's ability to sustain advantages both because workers are less likely to leave and because even if they do leave they cannot easily apply their firm-specific knowledge elsewhere. 
Interestingly, despite the fact that competitive advantage research focuses heavily on firmspecific human capital, an emerging body of strategy research focuses explicitly on general and industry-specific human capital. This is a clear acknowledgement that such human capital can be valuable and rare and is thus important in its own right, but this literature does not theoretically link general human capital to sustained competitive advantage. For example, Somaya, Williamson, and Lorinkova (2008) describe how law firms may gain revenue when attorneys move to the client side. Zenger (1992) studies how small firms may be able to attract and retain certain types of human capital through their ability to customize incentive contracts. These studies highlight novel sources of value creation from general human capital, but do not clarify how much revenue is captured by the employees. If employees capture the value from their general human capital, most strategy scholars would assume that there is no competitive advantage - i.e., an advantage may exist if the firm retains valuable human capital for less than the use value. While the value creation abilities of both firm-specific and general human capital are well established, it is less clear when firm-specific human capital may fail to support competitive advantage or when general human capital can generate sustained advantage.

\section{ESTABLISHING BOUNDARY CONDITIONS FOR THE FIRM-SPECIFIC HUMAN CAPITAL STORY}

The logic underlying the strategy literature’s traditional conceptualization of firm-specificity as an isolating mechanism is appropriate in some contexts, but there are many real-world contexts where this logic fails. This section develops in detail three important and largely ignored boundary conditions that constrain the applicability of the firm-specific human capital story when seeking to explain sustained competitive advantages. 
Heterogeneous Value of the Portfolio of Worker Skills

The logic underlying mobility constraints due to firm-specific human capital relies on a key assumption in the labor economics literature that conflicts with one of the core assumptions of the resource-based theory of the firm. While labor economists typically treat firms as homogeneous in order to explore labor markets more broadly, resource-based theorists explicitly assume heterogeneity in firm resources. Thus, the very definition of general human capital must be reexamined in light of a world where firms have unique portfolios of resources and capabilities. Specifically, even though such skills are widely applicable in other firms, their use value may differ considerably between firms due to different technologies, product markets, and complementary assets (Teece, 1986). Accordingly, if a rival firm has more productive complementary assets, a worker's general skills may be more highly valued externally than at the current employer. This may overshadow any firm-specific skills that are not valued externally, thereby facilitating mobility despite the presence of firm-specific skills.

This distinction supports treating workers as having a portfolio of skills where if one element of the portfolio restricts mobility, another may enhance mobility. Accordingly, it is critical to analyze the nature of entire portfolios of skills rather than any single skill in isolation. A single skill that has low applicability outside of the current context may have low exchange value and, therefore, rival firms will not rationally compensate workers for that skill. In practice, however, workers have portfolios of both general and firm-specific skills (Lazear, 2009). Shifting focus to the individual's portfolio of skills highlights the need to consider labor market demand for all the worker's skills simultaneously rather than any isolated skills individually.

The risk of losing workers to firms with more productive complementary assets increases as the relative importance of firm-specific human capital decreases. So, in contexts where Lazear's 
(2009) claim that general human capital creates more value than firm-specific human capital is valid, the incremental wage attributable to firm-specific skills is quite small, and consequently the productivity difference required for rivals to poach employees with firm-specific skills is also small. In this context, the firm-specific human capital may not limit employee mobility.

Consider, for example, a software developer with expertise in optimizing video streaming technologies who works at a small firm developing software for insurance companies. Her skills are used mostly to create and stream tutorials to clients, and she has acquired substantial firmspecific human capital. For example, she can organize teams, is well connected within the company, can navigate the internal bureaucracy to get things accomplished, and understands the complexities of the firm's proprietary modules. However, suppose Google wants access to her streaming video optimization skills. Because streaming video optimization creates far more value at Google than it does at her current employer, Google may be willing to compensate her more for her general skills than her current employer is willing to compensate her for both her general and firm-specific skills; thus, her firm-specific skills may not bind her to her current employer.

This example demonstrates that focusing on individual skills in isolation provides an insufficient and perhaps misleading understanding of how human capital influences mobility. Focusing instead on portfolios of skills highlights the important observation that firm-specific skills may not restrict mobility if an employee's general skills are more valuable to other firms. This idea yields the following boundary condition on extant human capital logics:

Boundary condition 1: A necessary condition for firm-specific human capital to function as an isolating mechanism is that the exchange value of workers' general human capital is no greater than the use value of workers' full portfolio of human capital in the focal firm (holding constant supply-side constraints on worker mobility). 


\section{Imperfect Information and Exchange Value}

In addition to focusing on portfolios of worker skills rather than isolated skills, the informational problems in real labor markets suggest the need to revisit a core underlying assumption embedded in traditional human capital logic: the tight coupling between demand-side mobility constraints and skill specificity. In the traditional logic, if skills are imperfectly transferrable or inapplicable at rivals, then alternative employers derive low use value from that skill. It follows that these skills have low exchange value. This coupling between specificity and exchange value requires sufficient information in the labor market for alternative employers to observe and properly value skills in an alternative context.

Real labor markets are fraught with information problems, however, making it very difficult for hiring firms to evaluate the human capital any individual worker possesses (Chiang \& Chiang, 1990; Jovanovic, 1979). Given the challenges associated with assessing the value of a worker, especially one outside the boundaries of the firm, it is likely that firms will incorrectly value the skill portfolio of potential employees. However, firms can reduce their exposure to the risks associated with erroneous assessments by relying on signals such as personal recommendations (Granovetter, 1973) or previous employment relationships (Spence, 1973), or by offering low upfront compensation with the promise of greater rewards if the worker is revealed to be of high quality (Bidwell \& Briscoe, 2010; Gilson \& Mnookin, 1995). Although these mechanisms minimize exposure to risks, they do not solve the underlying issue that firms have limited ability to forecast the value of a skill portfolio when brought inside the organization.

If worker skill portfolios are incorrectly valued in the labor market, then it is possible that workers with portfolios of mostly general human capital may face low demand, while workers with portfolios of mostly firm-specific human capital may experience high external demand. In 
other words, rather than a tight coupling between the exchange value of a skill portfolio and the firm-specificity of the skills in that portfolio, the relationship may best be represented as a 2 X 2 table (demand-side mobility constraints $\mathrm{X}$ firm-specificity of the skill portfolio). This is shown in Figure 1 and is discussed in detail below.

[Insert Figure 1 about here]

The upper left and lower right quadrants of Figure 1 correspond to the traditional firm-specific and general human capital logics, respectively. These cells represent the mechanisms likely to be in play when there is tight coupling between demand-side mobility constraints and firm-specificity of worker skills. The upper right and lower left quadrants, however, represent scenarios not typically considered in the traditional human capital story. These quadrants capture scenarios when the market incorrectly values workers' skill portfolios. In the upper right quadrant the market undervalues a portfolio of highly transferrable skills. As a consequence, workers in this quadrant are relatively immobile, even though their skills are highly transferrable. Likewise, in the bottom left quadrant the market overvalues a portfolio of highly firm-specific skills. As a consequence, workers in this quadrant are highly mobile, even though their skills are imperfectly transferrable. Since these two quadrants illustrate departures from the traditional human capital logics, the following sections discuss these cells in more detail.

Undervalued general human capital. Firms may undervalue general human capital in real labor markets for at least two reasons. First, a general characteristic of labor markets is that there is incomplete information about the quality and quantity of workers' knowledge and skills (Berg, 1970; Jovanovic, 1979; Spence, 1973). This information problem is, in essence, the classic lemons 
problem (Akerlof, 1970). Firms cannot evaluate whether the prospective employee is a high or low quality worker, which causes them to offer wages as if they were hiring lemons. The lemons problem leads to high-quality workers being undervalued in the labor market because their true quality is imperfectly observable to outsiders.

Second, firms may be able to observe workers' skills, but may be unwilling to pay the full use value of those skills due to some other stigma attached to the worker. For example, even if lawyers' general skills appear to be quite valuable, law firms may be less willing to hire lawyers who worked at stigmatized law firms (Rider, Negro, \& Roberts, 2011). A similar process of systematically incorrect employer assumptions about productivity may allow discrimination to persist in labor markets (Starbuck, 1993). In these situations workers have general skills that are relatively easy to apply elsewhere, and may have high use value elsewhere, but the labor market prices these skills too low due to incorrect collective perceptions.

Overvalued firm-specific human capital. Just as firms may undervalue a worker's bundle of general human capital, they may overvalue a worker's bundle of firm-specific human capital. Firm-specific human capital can provide a strong signal for valuable underlying general skills for at least two reasons. First, valuable general human capital may be necessary before workers can successfully acquire firm-specific human capital (Ployhart, Weekley, \& Ramsey, 2009; Ployhart, Van Iddekinge, \& MacKenzie, 2011). Second, valuable general human capital may be codeveloped as workers make highly firm-specific investments (Morris, Alvarez, Barney, \& Molloy, 2010). Accordingly, an employer seeking a worker who is willing and able to make substantial firm-specific investments may target people who have made such investments elsewhere, even if the prior investments are not transferable because workers’ past firm-specific investments signal 
the willingness and ability to make future investments. In this case, workers' investments in firmspecific skills may actually increase their market value.

However, firm-specific human capital may not always accurately signal valuable underlying general human capital. Consider, for example, a business school dean who demonstrates great fundraising success at her current institution. Rivals may observe the success and attribute it to some underlying general ability of the dean to raise funds when, in fact, the success may rely on highly idiosyncratic knowledge about the alumni of that particular school. A rival might hire this dean away, only to discover that she is unable to recreate the necessary alumni-specific knowledge in the new setting. In this case, the knowledge is not transferrable and the complementary asset is not easily recreated in the new setting. ${ }^{5}$

In the dean example, incomplete information regarding the value of worker skills in alternative organizations drives a wedge between workers' exchange value and the true use value of their skills. While the implications of decoupling exchange value from firm-specificity will be discussed in greater detail later, it is important to note that human capital that is systematically undervalued in the labor market may be a source of sustained competitive advantage because the focal firm can potentially retain workers with undervalued human capital for less than the use value of their skills. Likewise, overvalued firm-specific human capital may actually degrade a firm's competitiveness for two reasons: (1) the focal firm may have to share more rents with workers to persuade them to stay, and (2) workers with firm-specific human capital will have greater outside options making it more likely that they will leave and take their valuable knowledge and skills with them. Thus, the

\footnotetext{
${ }^{5}$ It is often assumed that firm-specific human capital is harder to observe than general human capital. If true, mispricing might occur more frequently for firm-specific human capital. As our analysis suggests, this may not mean that firm-specific human capital is systematically valued lower. In fact, consistent with Groysberg et. al's (2008) findings, rivals may assume firm-specific human capital is worth more than is ultimately the case.
} 
logic underlying firm-specific human capital as an isolating mechanism requires a second boundary condition. Formally:

Boundary condition 2: A necessary condition for firm-specific human capital to function as an isolating mechanism is that the exchange value of worker skills and the firmspecificity of those skills must be tightly coupled (holding constant supply-side constraints on worker mobility).

\section{Supply-Side Mobility Constraints}

The prior sections articulate important boundary conditions for extant human capital theory independent of supply-side constraints on worker mobility because traditional human capital theory relies solely on demand-side logics for constrained mobility. The explanation is that workers stay in their current firms because there is low external demand for their firm-specific skills, and workers change firms because of high external demand for their skills, independent of their desires to leave the current firm - i.e., workers are not averse to changing firms and always choose the employer that offers the highest wage. These simplifying assumptions have led many human capital scholars to ignore supply-side mobility constraints.

A variety of labor market imperfections in real labor markets may constrain employee mobility independent of the specificity of their human capital. While a full list of all labor market imperfections that can support competitive advantage is beyond the scope of this paper, two important imperfections are presented: mobility costs and information asymmetries. Each of these imperfections can constrain the mobility of employees with valuable human capital and thus facilitate creating and sustaining human capital-based competitive advantage.

Mobility costs. Search, bargaining, and switching costs hinder employee mobility because it is often costly for workers to search for alternative jobs, negotiate with their current employers or switch to new jobs. In many cases, workers will prefer to avoid these costs, which can effectively 
immobilize key employees (Wright et al., 1994). Even where workers’ knowledge and skills are in high demand, mobility costs may make them behave as though they had no other viable alternatives. Accordingly, as mobility costs decrease, mobility rates increase (Stevenson, 2009), as does the speed of finding new jobs (Kuhn \& Skuterud, 2004).

Some important examples of factors that influence the mobility costs borne by employees include idiosyncratic employee preferences and legal restrictions. First, idiosyncratic worker preferences for a given employer may increase mobility costs. For example, if firms can offer unique inimitable compensation packages that cater to individuals’ idiosyncratic preferences, then firms can potentially attract and retain highly productive employees with general human capital. These packages may consist simultaneously of factors that firms actively create and offer to employees (such as carefully designed medical benefits packages) as well as factors that function more like economic externalities (such as proximity to family). While financial compensation and market-based benefits are easily imitable, non-pecuniary rewards may be impossible or costly to imitate. For example, firms may offer access to unique social networks or an environment where specific values are nurtured (e.g., firm stability, ethical behavior, faith, etc.) that cannot be easily recreated in another firm. The matching of unique incentives to idiosyncratic worker preferences may make it unlikely that people will quit, even if they have broadly transferable human capital and are offered a higher wage. Firms certainly differ in their ability to design incentive contracts, so this could be an important source of variation in the ability to attract and retain individuals with valuable human capital (Rousseau, 2005; Rousseau, Ho, \& Greenberg, 2006; Zenger, 1992).

If individuals have very strong geographic preferences, they may rationally choose to search in locally thin markets. For example, hospitals and universities in small towns often act as local monopsonies. If they are the only buyers of medical and academic talent in a region, then they can 
use their market power to retain highly productive employees at financial discounts relative to rivals in regions with more competitive labor markets. Individuals with strong geographic preferences will not switch jobs to join rivals in less desirable regions because their total utility (which includes the utility derived from their compensation package and the utility derived from their location) is greater than the total utility associated with a higher-paying position in a lessdesirable location. As a result, monopsonists in desirable locations can attract and retain employees at a discount due to the non-pecuniary benefits associated with the location.

Legal institutions, such as non-compete agreements and patent enforcement, also create frictions in otherwise freely operating labor markets. For example, Marx, Strumsky, and Fleming (2009) demonstrate that non-compete agreements not only restrict the use of firm-specific human capital, but in many cases the use of general human capital as well. In a similar vein, Agarwal, Ganco, and Ziedonis (2009) show that employers’ reputations for aggressive patent enforcement discourage mobility of inventors. Thus, the existence of legal institutions can provide significant market imperfections. Legal restrictions may have an impact even when they are unenforceable since employees must bear the legal and emotional costs of challenging such agreements and thus are less likely to supply their effort to rival employers.

Information asymmetries. For the same reasons that firms have limited information on the use value of a potential employee, it may be hard for employees to know their exchange value in the labor market. If workers underestimate their exchange value, they may not search for outside options needed to bargain for higher wages. This constitutes a supply-side mobility constraint because workers choose not to explore supplying their labor on the external labor market.

While there is limited information on both sides of the labor market on the value of an individual inside a firm, if employers know more about the use value of the full portfolio of worker 
skills than employees know about their own skills, they can leverage this knowledge to decrease worker mobility, even those with general human capital. If firms create an environment where it is very costly for workers to assess the use value of their own human capital and where workers undervalue their contribution, then these workers may not know that they can bargain for higher compensation. This logic is particularly relevant in a dynamic context. Even if workers can accurately assess their use value and/or their exchange value in the labor market in one time period, it may not be possible for employees to predict how their internal and external value will change over time.

In summary, employees can have constrained mobility in the absence of any firm-specific human capital due to supply-side factors. While there are many labor market imperfections that constrain mobility and support sustained competitive advantage, the two presented here serve to demonstrate that a reliance on firm-specificity as an isolating mechanism in the strategy literature leads to theory that is incomplete: there are many alternative factors that reduce employee mobility even in the absence of firm-specific human capital. Likewise, supply-side factors could enhance mobility if they are particularly low - i.e., if a firm is of particularly low desirability, workers may generally prefer to leave. If so, the low supply-side constraints could outweigh the demand-side constraints imposed by firm-specific human capital. In other words, very low supply-side constraints may provide a "push" factor causing workers to actively pursue alternative employment options even if they incur a financial loss. Thus, the logics underlying firm-specific human capital as an isolating mechanism can only hold when supply-side constraints are not so low as to function as push factors. Formally,

Boundary condition 3: A necessary condition for firm-specific human capital to function as an isolating mechanism is that supply-side mobility constraints cannot be so low that workers are willing to incur substantial financial costs to move - i.e., supply-side factors are not pushing workers to leave. 


\section{FROM BOUNDARY CONDITIONS TO A MORE COMPREHENSIVE \\ FRAMEWORK}

The three boundary conditions developed earlier demonstrate some important limitations on the assertion that firm-specific human capital will act as an effective isolating mechanism. This section builds on those boundary conditions to provide a more comprehensive framework for the conditions under which human capital may be isolated and, therefore, facilitate sustained advantages. By so doing, we advance theory of human capital-based competitive advantages beyond a simple reliance on firm-specificity to accommodate demand- and supply-side mobility constraints. Firms' bundles of complementary human assets, such as team members and managers, and complementary non-human assets, such as production technologies and employee culture, affect both the demand-side factors and supply-side factors that affect individual workers. These factors then combine with the heterogeneous preferences and skills of individuals to determine employee mobility. In Figure 2 we present a 2 X 2 X 2 framework (demand-side constraints X supply-side constraints $\mathrm{X}$ skill specificity) that highlights how firm variation in complementary assets leads to different demand- and supply-side constraints and can thus facilitate the retention of key employees. ${ }^{6}$

Insert Figure 2 about here

In Figure 2, the column at the far right highlights scenarios that rely on general human capital (low specificity) while the left column reflects scenarios involving firm-specific human capital.

\footnotetext{
${ }^{6}$ While complementary assets that affect demand- and supply-side constraints can be costly, and firms vary in their investments in such constraints, we temporarily hold these costs constant across firms. This simplifying assumption allows inferences regarding which cells in Figure 2 may facilitate sustained human capital-based advantages.
} 
Extant logics suggest that competitive advantages are most likely to occur on the left-hand side since firm-specific skills are believed to function as an isolating mechanism. On the other hand, traditional logic would suggest that competitive advantages will not occur on the right-hand side since skills are easily applicable in multiple contexts. By separating demand-side constraints from firm-specificity and simultaneously considering supply-side constraints, Figure 2 offers a richer description of the heterogeneity of real-world outcomes than extant theory.

An important insight from Figure 2 is that firm-specificity may be an important factor in determining whether the firm is able to realize a sustainable competitive advantage from human capital, but it is not the dominant factor. Figure 2 expands beyond firm-specificity to demonstrate that firms can acquire human capital-based competitive advantages from key workers when the firm's complementary assets result in supply-side mobility constraints that dominate demand-side mobility constraints. In other words, competitive advantages may accrue when key workers' attachments to their employers dominates their ability to demand exchange value outside the firm. As argued previously, firm-specificity may influence demand for a worker's skills and thus support demand-side constraints; however the mapping between the skill specificity and worker overall exchange value is imperfect. As a consequence, an over-emphasis on firm-specificity does not match the breadth and complexity of outcomes in real organizations.

Cells 1 and 8 in Figure 2 most resemble the traditional firm-specific and general human capital logics, respectively. Cell 1 captures the scenario in which workers have portfolios of highly firmspecific skills that are not transferrable elsewhere, the market correctly evaluates the external value of those skills, and there is a high level of supply-side factors that make the firm desirable to workers. For example, consider a business school faculty member at a top university who invests heavily in case writing expertise. The complementary assets of the business school allow the 
school to create more value from the faculty member's case writing skills than other institutions. If her investment in case writing corresponds to a smaller investment in research, the external demand for that faculty member's skills may decrease. However, if the professor enjoys case writing and the status attached to the university, she may prefer to stay regardless of external demand for her human capital. In other words, the underlying complementary assets of job design and school status combined with the faculty member's preference for these factors create a strong supply-side constraint to her mobility. In this case, supply- and demand-side factors are aligned and effectively limit mobility. Accordingly, Cell 1 actually presents a significantly stronger case for sustained competitive advantage than is normally expressed in the strategy literature, where the supply side factors are largely ignored.

In contrast, Cell 8 captures the scenario in which workers have portfolios of highly transferrable skills, the market correctly values these skills, and there are no supply-side factors that would cause workers to want to stay in their current firms. For example, superstar athletes tend to have highly transferrable skills that are easily observable and do not rely heavily on the skills of teammates and coaches; therefore, their value in alternative organizations is relatively predictable. In the absence of strong idiosyncratic preferences for unique complementary assets that would cause a superstar to want to stay with a team, such as preference for the city, enjoyment of the playing style, appreciation for the brand, and so forth, such athletes are highly mobile. We would not expect human capital to be isolated in this situation. Again, the supply- and demandside factors are aligned, but this time they both promote the mobility of human capital. As such, the scenario in Cell 8 offers a considerably stronger case for why a sustained advantage would not emerge than the cases typically presented in the strategy literature. 
While some real-world scenarios do align with the standard assumptions connecting firmspecificity and competitive advantage (and thus map roughly into Cells 1 or 8), many scenarios do not fit into the extant framework and thus fall into the other cells of Figure 2. Since these cells depart from traditional logics connecting human capital to competitive advantage, they are discussed in detail below along with illustrative examples.

\section{Cell 2: General Human Capital As a Source of Sustained Advantage}

Workers with general human capital can be effectively isolated when the market incorrectly values that human capital and when supply-side factors cause workers to want to stay in their current firms. For example, Starbuck (1993) describes the early success of Wachtell through hiring talented Jewish lawyers at a time when many other law firms were discriminating against Jews. These lawyers were highly skilled and highly qualified with largely general skills, but the market undervalued them because of an unrelated stigma. Since Wachtell was willing to hire these lawyers, they won a great deal of support and appreciation from the Jewish community. As a consequence, Wachtell became the employer of choice for talented Jewish lawyers, even after the market stigma abated. The resource of the firm's reputation among these lawyers combined with low external demand for these lawyers led to a sustainable human capital advantage through primarily general human capital.

The surprising result from this cell is that general human capital can be isolated and, as a consequence, can possibly be a source of sustained competitive advantage. When general human capital is undervalued in the labor market and when workers prefer to stay at their focal firms, then the focal firm is well positioned to realize advantages from that human capital. Formally,

Proposition 1: Firms are most likely to realize sustained advantages from general human capital when both demand-side and supply-side mobility constraints are high. 


\section{Cell 7: Firm-Specific Human Capital Fails to Confer an Advantage}

If the market overvalues a worker's firm-specific human capital and the worker wants to leave the focal firm, then the combination of low supply- and demand-side constraints will likely lead to high mobility. Consider, for example, the previously mentioned business school dean who exhibits unprecedented fundraising success due to her deep knowledge of the alumni base (a firmspecific skill), but who is also discouraged by university administrators and/or local weather conditions. Other business schools may see her fundraising success and incorrectly attribute that success to her general fundraising ability when it is more correctly attributed to the idiosyncratic match between her alumni knowledge and that particular institution. As a consequence, other schools may place a high market price on her highly firm-specific skills. If she also wants to leave due to her individual preferences, then this dean is likely to move to another institution. Despite her highly firm-specific human capital, her current employer may be unwilling to offer enough compensation to keep her in place.

The surprising result from this cell is that when both demand- and supply-side constraints are low, even workers with portfolios of highly firm-specific human cannot be isolated. Thus, firms that rely heavily on firm-specific human capital for business performance may face significant retention challenges when both demand-side and supply-side constraints are low; in the aggregate, these firms will struggle to retain workers with valuable firm-specific human capital. In such cases, the focal firm will be unable to realize any long-term value from this highly firm-specific human capital. Formally,

Proposition 2: Firms are unlikely to realize advantages from firm-specific human capital when both demand-side and supply-side constraints are low. 


\section{Cells 3-6: Conflicting Supply- and Demand-Side Factors}

Up to this point, we have addressed the situations in which supply- and demand-side factors are aligned (both high or both low). However, the middle four cells in Figure 2 deal with situations in which one factor is high and the other is low. For these cells it is unclear, ex ante, whether a firm will be able to isolate human capital and thereby realize sustained advantages. The result will ultimately depend on the relative strength of the supply-side and demand-side constraints.

For example, Cell 3 might reflect a scientist who has made lifelong investments in a firm's proprietary technology, but who would prefer to leave the firm for any number of reasons. She must choose whether the loss in income due to leaving her firm-specific skills behind overcomes her negative utility associated with staying. When the negative utility of staying is shared by many employees within a firm, then there is a higher likelihood that some of those employees will be willing to incur monetary losses to avoid this negative utility. The overall balance of decisions to stay and decisions to go, however, relies on the relative intensity of the negative utility and the relative intensity of monetary loss incurred by employees by moving. In contrast, Cell 4 might capture Wachtell if their Jewish lawyers desired to exit the organization. If the lawyers wanted to move, but the market undervalued their human capital, then they would have had to choose between the negative utility of staying with Wachtell versus the loss in income from changing firms.

Cell 5 is likely a vexing cell for managers because workers possess skills that are uniquely valued in the focal firm, but, for some reason, the external market incorrectly places a high value on them. In order to retain these workers, managers must find supply-side constraints to hold them in place, when the demand-side constraints should be holding them in place. An example may be the dean whose success is driven by her idiosyncratic knowledge about the alumni base but who 
nevertheless has many outside options due to fundraising success. The focal institution will need to find supply-side mechanisms to continue to hold this dean in place, such as surrounding the dean with enjoyable and respected colleagues or providing a spousal position that other institutions cannot match. When many workers with firm-specific human capital face inflated outside options, then the firm, in aggregate, must ensure that supply-side constraints overcome the inflated market demand in their efforts to retain workers.

Finally, Cell 6 captures a fairly common situation in real labor markets when skills are highly valued elsewhere but workers prefer to stay in the focal firm. For example, academics tend to have highly visible and easily valued general skills (e.g., publication ability). However, if they become deeply entrenched in their communities because their families have developed dense networks of friends (Lee, Sablynski, Mitchell, Burton, \& Holtom, 2004; Mitchell, Holtom, Lee, Sablynski, \& Erez, 2001), because they have built their dream homes, or because their offices are so messy that it is not feasible to pack up their belongings, they may be highly immobile despite very general skill sets. Alternative institutions would need to offer utility greater than the exchange value of the academics' general human capital and the returns from these other investments. If alternative employers appropriately value the skills of the academic, they will be unwilling to offer greater compensation than that. In this case, the academics have effectively made firm-specific investments that keep them in place, yet they do not possess firm-specific human capital.

Ultimately, the competitive implications associated with employing workers in these middle cells are unclear without the ability to determine when the supply-side or demand-side factors dominate and the ability to assess the imitability of the complementary assets that underlie the mobility constraints. Theoretically, firms can isolate human capital when the high constraint is stronger than the low constraint - e.g., when high supply-side constraints dominate low demand- 
side constraints or vice versa. Further, firms can derive sustained competitive advantages if the constraints are not imitable by rivals. Practically, however, the challenge of identifying sustained competitive advantage in these cells is more difficult. This practical difficulty highlights one of the primary paths forward for future research, discussed in more detail in the following sections.

\section{DISCUSSION AND IMPLICATIONS FOR A NEW STRATEGY RESEARCH AGENDA}

This paper demonstrates the need to rethink the role of human capital in generating sustainable competitive advantages. Many have emphasized that general human capital cannot be a source of competitive advantage or that it poses special management challenges (Coff, 1997; Hatch \& Dyer, 2004). However, we suggest that general and firm-specific human capital may face the same management challenges in some contexts; thus, this commonly accepted emphasis on the specificity of human capital is overly simplistic and too heavily based on theoretical assumptions that are inconsistent with observations of actual labor markets.

\section{Rethinking Human Capital As a Source of Competitive Advantage}

A more realistic framework of labor markets that accounts for both supply- and demand-side constraints can identify when firm-specific human capital may fail to support competitive advantages and, conversely, when general human capital may support them. Drawing on such a framework, we have identified critical boundary conditions on the notion that firm-specific human capital will function effectively as an isolating mechanism. Most importantly, the literature draws on demand-side logic that is binding only when (1) workers' general skills are not valued so highly at other firms that it compensates for firm-specific skills that may not be highly valued, (2) external employers can observe firm-specific skills and offer lower wages to workers who have invested in them, and (3) there are no supply-side factors that promote mobility, even if there is low external demand for skills. Scholars invoking the firm-specific human capital logic may be well served by 
theoretically and empirically considering how these boundary conditions affect their research settings. Indeed, these binding conditions are often violated in real labor markets, such that workers with firm-specific human capital may be far more mobile and tradable than is typically assumed. In such cases, in contrast to prior treatments in the literature, such skills are very unlikely to effectively hold valuable human capital in place.

Furthermore, supply- and demand-side factors may constrain mobility even for workers with general human capital. On the demand side, firms' complementary resources that create information asymmetries or utilize idiosyncratic portfolios of general skills may engender very thin markets, even if the skills are not customized to a given firm. Of course, supply-side factors apply to both general and firm-specific human capital, as idiosyncratic worker preferences for firms' heterogeneous resources may push them to stay with a given employer even if their skills are worth more elsewhere. This also represents a key departure from the previous strategy literature, which has, for the most part, dismissed general human capital as a source of advantage.

Accordingly, we have advanced knowledge of the micro-foundations of competitive advantage by more carefully specifying conditions under which individuals with valuable human capital can be effectively isolated and their human capital leveraged to realize advantages (Coff \& Kryscynski, 2011; Felin \& Hesterly, 2007; Foss, 2011; Ployhart, Weekley, \& Baughman, 2006). Thus, a firm’s ability to generate advantages from human capital depends not only on the specificity of worker skills, but also on the firm's ability to create and/or leverage both supply-side and demand-side mobility constraints to better retain human capital at discounts relative to rivals. As has been argued by others, when the firm is better able to retain talented human capital, that firm is better positioned to utilize these individuals to create and leverage firm-level resources to enhance their competitive capabilities (Ployhart \& Moliterno, 2011; Ployhart et al., 2006). 


\section{A New Research Agenda for Human Capital-Based Competitive Advantage Scholars}

We focus on three opportunities to extend theory, based on the high-level framework presented in the prior sections. First, developing a more systematic and complete typology of labor market imperfections that affect demand- and/or supply-side mobility constraints will help researchers develop theory that addresses the full range of factors that are necessary to understand when human capital can be a source of sustained competitive advantage. Second, empirically testing the conditions under which conventional logics fail may help refine and validate the boundary conditions and propositions presented here. Third, examining the relative intensity of these labor market imperfections on demand- and supply-side mobility constraints will help researchers determine when human capital is most likely to facilitate competitive advantage in the indeterminate cells of Figure 2 (i.e. Cells 3-6). This advance, when integrated with recent research from strategic human resource management, may help scholars identify new channels through which managers can leverage and/or overcome both demand- and supply-side mobility constraints in their efforts to realize competitive advantages.

Broader focus on labor market imperfections. The first opportunity for new inquiry is in theorizing and operationalizing a broader range of factors that may limit the mobility of human capital - i.e., a broader set of labor market imperfections. Again, the extant strategy literature has reflected an implicit assumption that failures in the market for firm-specific human capital hinder mobility while workers with only general human capital remain highly mobile. Arguments presented here have focused on the role of complementary assets and highlighted how these can make firm-specificity a poor proxy for immobility given the important roles of supply- and demand-side constraints. As such, the analysis suggests a shift should be made in the way strategic human capital researchers approach theories of human capital-based competitive advantage. 
Rather than relying only on the specificity of human capital, researchers should explore the full range of factors that isolate human capital in a manner that allows some firms to enjoy sustained advantages.

Peteraf (1993) provides a useful starting point by identifying several classes of ex post limits to resource mobility. In line with our focus on complementary resources, she includes nontradability of resources, switching costs, the co-specialization of assets, and high transaction costs. To these limits, it is important to understand how individual preferences (such as an attraction toward social ties, geographies, organizational cultures, and other organizational institutions) limit the movement of human capital across organizations. While the present arguments touch on these factors, further research should expand this list and explore the theoretical implications of these factors in greater depth rather than relying only on firm-specificity as a proxy for the interaction of multiple factors that restrict employee mobility.

Empirically testing when extant logics fail. While Propositions 1 and 2 articulate the conditions under which firms are most and least likely to realize competitive advantages from general and firm-specific human capital, respectively, empirical tests of these propositions would help identify whether these exceptions are meaningful in practice or only in theory. Specifically, scholars may undertake studies of human capital-based competitive advantage in industries that rely primarily on general human capital, such as the legal, software, and medical practice industries. Such studies may demonstrate how variances in certain supply-side mobility constraints affect retention of critical workers, labor productivities, and overall firm performance relative to rivals. Likewise, scholars may focus on industries that rely heavily on firm-specific human capital, such as bio- and nano-technology, to empirically explore whether supply-side “push” factors drive workers to sacrifice the value of their firm-specific human capital by changing 
employers. While recent years have seen an increase in studies exploring the strategic implications of workers’ mobility (Aime, Johnson, Ridge, \& Hill, 2010; Almeida \& Kogut, 1999; Rosenkopf \& Almeida, 2003; Shaw, Duffy, Johnson, \& Lockhart, 2005), analyzing these results through the lens of intertwined demand- and supply-side constraints would advance the field's understanding of the phenomena by illuminating the antecedents of mobility and demonstrating that strategic decisions of workers and firms interact to determine mobility.

The logic in this paper also suggests the need to critically evaluate the growing body of empirical work connecting firm-specific human capital and competitive advantage (e.g., Hatch \& Dyer, 2004; Ployhart et al., 2011; Wang et al., 2009). This empirical research may have limited generalizability for three reasons. First, there are clear boundary conditions to extant theory underlying firm-specific human capital as an isolating mechanism, and future research should recognize and explore these boundary conditions. Industry- or firm-level analyses that explore the contexts where the three boundary conditions hold would be valuable to future work that explores the specificity of human capital. For example, work that details conditions under which general human capital is likely to be undervalued or firm-specific human capital is likely to be overvalued by the market would be an important base for future empirical work. Second, extant measures of firm-specific human capital tend to conflate firm-specificity with external market value. Scholars have used proxies such as worker tenure (e.g., Harris \& Helfat, 1997), on-the-job training (e.g., Hatch \& Dyer, 2004; Ployhart et al., 2011), or patent self-citations (Wang et al., 2009), but these measures do not capture whether skills are actually applicable to other firms. If firm-specificity and exchange value are not tightly coupled in some contexts, then these standard proxies for workers' limited mobility are problematic. For example, long tenure profiles within a firm may suggest the firm is better able to retain workers independent of the specificity of the workers' skills. 
We call for the field of strategy to emphasize measures that more directly capture supply- and demand-side constraints, such as employee satisfaction, strength of employee networks, and value of external job offers, while simultaneously refining measures that more directly capture the extent to which worker skills are deployable in alternative contexts. Third, previous studies have emphasized isolated workers' skills instead of examining the entire portfolio of skills possessed by workers. Because workers' skills are inseparable, the worker is the appropriate level of analysis, not an isolated skill. As such, future research that addresses the exchange value of workers' full portfolio of skills would be an important contribution.

Factors underlying the intensity of supply and demand-side constraints. Beyond expanding the list of imperfections that may constrain worker mobility, there is also an opportunity to study factors that influence the intensity of these imperfections. For example, research exploring the strength of human resource (HR) systems (Bowen \& Ostroff, 2004) suggests that strong HR systems may increase the intensity of supply-side mobility constraints in firms. Understanding what impacts the relative intensity of these constraints may shed light on the indeterminate cells in Figure 2. Specifically, if theory can identify the conditions under which demand-side constraints will be high, then we may be better positioned to predict when these constraints will dominate supply-side factors and, therefore, lead to sustained human capital-based competitive advantages.

These ideas suggest a new venue for research on human capital management capabilities. A richer understanding of the role of complementary assets on the interrelationship of supply- and demand-side constraints in supporting competitive advantage offers a new foundation on which strategic human resource management (SHRM) practices contribute to sustained competitive advantages. For example, numerous studies link SHRM practices to firm performance (e.g., 
Arthur, 1994; Macduffie, 1995; Wright, Gardner, Moynihan, \& Allen, 2005), but few have specifically associated these practices to capabilities to create, leverage, and/or overcome these mobility constraints. Indeed, recent SHRM scholars have called for work to open the "black box" connecting SHRM practices and firm performance (Becker \& Gerhart, 1996; Collins \& Clark, 2003; Wright, Gardner, \& Moynihan, 2003). One way to open that black box may be to explicitly connect these practices to the creation of specific supply-side constraints and/or to show how these practices may overcome supply-side constraints imposed by other firms.

Similarly, firms may be able to generate advantages through their strategic factor market activities in markets for human capital (Barney \& Wright, 1998). However, extant literature has not systematically examined these demand-side factor market capabilities and how firms acquire or build them. In this vein, how can firms identify and value general human capital that other firms overlook? One possible answer is to hire workers from stigmatized firms, schools, or social categories. Indeed, some firms, like Wachtell, do seem to actively engage in such hiring practices, but this has not been well researched and documented as a source of competitive advantage. This is a fruitful area of inquiry that connects strategy and strategic human resource management.

Analogously, there are supply-side strategies like recruiting people who have a strong interest in the company due to its location or some other personal preference. Clearly firms take advantage of such opportunities when they see them, but this has not been the subject of research in the strategy literature. As a result, the extent to which firms are heterogeneous in their ability to exploit such supply-side preferences is not entirely clear.

While it is likely that specific capabilities are linked to exploiting supply- and demand-side opportunities in strategic factor markets, these have not been the subjects of strategy research. Almost certainly, such capabilities will not correspond to formulaic approaches that are frequently 
adopted in the SHRM literature since these practices would tend to be widely adopted over time and would no longer be a source of firm heterogeneity (Chadwick \& Dabu, 2009).

In each of these cases, we stress the importance of human resource practices in supporting sustained competitive advantage by constructing and overcoming demand- and supply-side constraints. However, there is a need to look well beyond the traditional policies and best practices adopted in human resource departments. Some of the most critical human resource decisions take place in executive suites without the input of human resource professionals. Others take place at the shop floor level but also do not involve human resource professionals. These practices may be less systematic and may also be tied to specific individuals' management styles. However, these idiosyncrasies may also make them harder to imitate than more systematic and professional policies that have been studied thus far in the received literature.

\section{Managerial Implications}

By extending the view of human capital as a source of competitive advantage to examine a richer set of labor market imperfections, this research supports a variety of approaches that firms can take to construct human capital-based competitive advantages, including compensation design, employee selection, and job design. For example, managers can design packages that are cospecialized with employee and contextual idiosyncrasies such that they are unique and inimitable. If such packages provide employees with utility that is equivalent to a rival's offer, but at a lower cost, managers can effectively create supply-side constraints. Indeed, these idiosyncratic compensation packages may be costly to imitate, resulting in sustained advantages. Such lowcost, high-utility, firm-specific packages may include access to social networks, locations, or perquisites like a work environment that rivals are unable/unwilling to imitate (e.g., a faith-based 
or "green" culture). This capability is particularly important in Cells 5 and 6 of Figure 2, where there is high external demand for workers' skill portfolios.

In conjunction with offering firm-specific compensation packages, managers can focus on selecting employees that complement the firms' idiosyncratic attributes. For example, by hiring employees that share a common set of values, it becomes easier to sell these values to subsequent employees. If Google wants to offer the ability to work alongside smart and creative programmers, then selecting these employees is essential to being able to offer this benefit to future employees (Coff \& Kryscynski, 2011). Over time, this path-dependent component of building the capability can make it hard for other firms to catch up (Dierickx \& Cool, 1989).

Managers can also limit the mobility of their employees by utilizing idiosyncratic portfolios of human capital more efficiently than rivals. In this way, they can create a gap between the value of the individual at their firm relative to other firms and thus retain the employee at an economic discount. Firms may be able to create more value from employees by designing jobs that utilize the full breadth of individuals' idiosyncratic skills by matching them to differences in technologies, markets, or complementary assets that rivals lack. Similarly, managers can design jobs that create information asymmetries and causal ambiguity that constrain worker mobility. Consider, for example, a hedge fund that uses a confidential algorithm to convert the research of a pool of stock analysts into buy and sell orders. No single analyst is aware of how much value his or her research creates; thus, rivals cannot easily poach key employees since their value is unclear. These examples highlight the strategic value of human resource practices in the resource-based view of the firm (Wright, Dunford, \& Snell, 2001) and describe some of the channels through which human resource managers can tailor jobs and benefits for an individual in order to increase supply-side constraints and thus support competitive advantage. 
From the manager's point of view, many of these approaches expose the firm to the risks associated with a bilateral monopoly. If a manager invests in designing a customized job or idiosyncratic benefits package to match a unique individual, then although the employee may not be movable, she knows that she may be very costly to replace and thus can hold up the firm. However, these concerns are more relevant for exploring who will appropriate rent from a competitive advantage than value creation (Coff, 1999; Peteraf \& Barney, 2003).

\section{CONCLUSION}

In sum, a lack of recognition of the boundary conditions of when firm-specific human capital restricts mobility has led to an over-reliance on firm-specificity as an isolating mechanism and has diverted the strategy literature from important lines of inquiry that would help illuminate the sources and nature of human capital-based competitive advantages observed in actual firms. This paper only scratches the surface of the many critical questions yet to be explored on the interactions of supply- and demand-side constraints on employee mobility that can support human capitalbased advantages. Furthermore, these questions have practical significance for managers seeking to generate and sustain competitive advantages. In many cases, these implications differ substantially from prescriptions that may be drawn from the extant strategy literature. Indeed, we hope to encourage bold new directions in both research and practice. 


\section{REFERENCES}

Agarwal, R., Echambadi, R., Franco, A. M., \& Sarkar, M. B. 2004. Knowledge transfer through inheritance: Spin-out generation, development, and survival. The Academy of Management Journal, 501-522.

Agarwal, R., Ganco, M., \& Ziedonis, R. H. 2009. Reputations for toughness in patent enforcement: Implications for knowledge spillovers via inventor mobility. Strategic Management Journal, 30(13): 1349-1374.

Aime, F., Johnson, S., Ridge, J. W., \& Hill, A. D. 2010. The routine may be stable but the advantage is not: competitive implications of key employee mobility. Strategic Management Journal, 31(1): 75-87.

Akerlof, G. A. 1970. The market for “lemons”: Qualitative uncertainty and the market mechanism. Quarterly Journal of Economics, 84: 488-500.

Almeida, P., \& Kogut, B. 1999. Localization of knowledge and the mobility of engineers in regional networks. Management Science, 45: 905-917.

Amit, R., \& Schoemaker, P. J. H. 1993. Strategic assets and organizational rent. Strategic Management Journal, 14(1): 33-46.

Arthur, J. B. 1994. Effects of human resource systems on manufacturing performance and turnover. Academy of Management Journal, 670-687.

Barney, J. B. 1991. Firm resources and sustained competitive advantage. Journal of Management, 17: 99-120. 
Barney, J. B., \& Wright, P. M. 1998. On becoming a strategic partner: The role of human resources in gaining competitive advantage. Human Resource Management, 37(1): 3146.

Bartel, A. P., \& Borjas, G. J. 1977. Middle-age job mobility: its determinants and consequences, NBER working paper No. 161.

Becker, B., \& Gerhart, B. 1996. The impact of human resource management on organizational performance: Progress and prospects. Academy of management journal, 779-801.

Becker, G. 1964. Human capital: A theoretical and empirical analysis, with special reference to education, University of Chicago Press.

Berg, I. G. 1970. Education and Jobs: The Great Training Robbery (Reprinted in 2003), New York: Praeger. Updated Percheron Press.

Bidwell, M., \& Briscoe, F. 2010. The Dynamics of Interorganizational Careers. Organization Science, 21(5): 1034-1053.

Bowen, D. E., \& Ostroff, C. 2004. Understanding HRM-firm performance linkages: the role of the“ strength” of the HRM system. Academy of Management Review, 29(2): 203-221.

Buchholtz, A. K., Ribbens, B. A., \& Houle, I. T. 2003. The role of human capital in postacquisition CEO departure. The Academy of Management Journal, 46(4): 506-514.

Campbell, B. A., Ganco, M., Franco, A. M., \& Agarwal, R. 2012. Who leaves, where to, and why worry? Employee mobility, entrepreneurship and effects on source firm performance. Strategic Management Journal, 30(1): 65-87. 
Chadwick, C., \& Dabu, A. 2009. Human resource management, and the competitive advantage of firms: Toward a more comprehensive model of causal linkages. Organization Science, 20: 253-272.

Chiang, S. H., \& Chiang, S. C. 1990. General human capital as a shared investment under asymmetric information. Canadian Journal of Economics, 23(1): 175-188.

Coff, R. W. 1997. Human assets and management dilemmas: Coping with hazards on the road to resource-based theory. Academy of Management Review, 22(2): 374-402.

Coff, R. W. 1999. When competitive advantage doesn’t lead to performance: The resource-based view and stakeholder bargaining power. Organization Science, 10(2): 119-133.

Coff, R. W., \& Kryscynski, D. G. 2011. Drilling for micro-foundations of human capital-based competitive advantages. Journal of Management.

Collins, C. J., \& Clark, K. D. 2003. Strategic human resource practices, top management team social networks, and firm performance: The role of human resource practices in creating organizational competitive advantage. Academy of Management Journal, 46(6): 740751.

Conner, K. R. 1991. A historical comparison of resource-based theory and five schools of thought within industrial organization economics: do we have a new theory of the firm? Journal of Management, 17(1): 121.

Dierickx, L., \& Cool, K. 1989. Asset stock accumulation and sustainability of competitive advantage. Management Science, 35(12): 1504-1511. 
Felin, T., \& Hesterly, W. S. 2007. The knowledge-based view, nested heterogeneity, and new value creation: Philosophical considerations on the locus of knowledge. The Academy of Management Review, 32(1): 195-218.

Foss, N. J. 2011. Micro-foundations for the resource-based view? Journal of Management, forthcoming.

Gathmann, C., \& Schönberg, U. 2010. How general is human capital? A task-based approach. Journal of Labor Economics, 28(1): 1-49.

Gilson, R. J., \& Mnookin, R. H. 1995. Foreword: Business lawyers and value creation for clients. Oregon Law Review, 74: 1.

Glick, H. A., \& Feuer, M. J. 1984. Employer-sponsored training and the governance of specific human capital investments. Quarterly Review of Economics and Business, 24(2): 91104.

Granovetter, M. 1973. The strength of weak ties. American Journal of Sociology, 6: 1360-1380.

Groysberg, B., Lee, L.-E., \& Nanda, A. 2008. Can they take it with them? the portability of star knowledge workers’ performance. Management Science, 54(7): 1213-1230.

Hall. 1993. A framework linking intangible resources and capabilities to sustainable competitive advantage. Strategic Management Journal, 14(8): 607-618.

Harris, D., \& Helfat, C. 1997. Specificity of CEO human capital and compensation. Strategic Management Journal, 18(11): 895-920. 
Hashimoto, M. 1981. Firm-specific human capital as a shared investment. The American Economic Review, 71(3): 475-482.

Hatch, N. W., \& Dyer, J. H. 2004. Human capital and learning as a source of sustainable competitive advantage. Strategic Management Journal, 25(12).

He, J., \& Wang, H. C. 2009. Firm innovative knowledge assets and economic performance: The asymmetric roles of incentive-and monitoring-based governance mechanisms. Academy of Management Journal, 52(5): 919-938.

Helfat, C. 1994. Evolutionary trajectories in petroleum firm R and D. Management Science, 40(12): $1720-1747$.

Jovanovic, B. 1979. Firm-specific capital and turnover. The Journal of Political Economy, 87(6): 1246-1260.

Kambourov, G., \& Manovskii, I. 2009. Occupational specificity of human capital. International Economic Review, 50(1): 63-115.

King, A. W., \& Zeithaml, C. P. 2001. Competencies and firm performance: Examining the causal ambiguity paradox. Strategic Management Journal, 22(1): 75-99.

Klepper, S. 2007. Disagreements, spinoffs, and the evolution of Detroit as the capital of the US automobile industry. Management Science, 53(4): 616.

Klepper, S., \& Sleeper, S. 2005. Entry by spinoffs. Management Science, 51(8)1291-1306. 
Kor, Y. Y., \& Leblebici, H. 2005. How do interdependencies among human-capital deployment, development, and diversification strategies affect firms' financial performance? Strategic Management Journal, 26(10): 967-985.

Kuhn, P., \& Skuterud, M. 2004. Internet job search and unemployment durations. American Economic Review, 94(1): 218-232.

Lazear, E. P. 2009. Firm-specific human capital: A skill-weights approach. The Journal of Political Economy, 117(5): 914.

Lee, T., Sablynski, C. J., Mitchell, T. R., Burton, J., \& Holtom, B. 2004. The effects of job embeddedness on organizational citizenship, job performance, volitional absences, and voluntary turnover. Academy of Management Journal, 47(5): 711.

Lepak, D. P., \& Snell, S. A. 1999. The human resource architecture: Toward a theory of human capital allocation and development. The Academy of Management Review, 24(1): 31-48.

Lippman, S. A., \& Rumelt, R. P. 1982. Uncertain imitability: An analysis of interfirm differences in efficiency under competition. The Bell Journal of Economics, 13(2) 418-438.

Macduffie, J. P. 1995. Human Resource Bundles and Manufacturing Performance: Organizational logic and flexible production systems in the world auto industry. Industrial \& Labor Relations Review, 48(2): 197-221.

Marx, M., Strumsky, D., \& Fleming, L. 2009. Mobility, skills, and the Michigan non-compete experiment. Management Science, 55(6): 875-889. 
Mitchell, T. R., Holtom, B., Lee, T., Sablynski, C., \& Erez, M. 2001. Why people stay: Using job embeddedness to predict voluntary turnover. Academy of Management Journal, 44(6): 1102-1122.

Morris, S., Alvarez, S., Barney, J. B., \& Molloy, J. 2010. Employee investments in firm-specific human capital and firm level competitive advantage. Working manuscript.

Neal, D. 1995. Industry-specific human capital: Evidence from displaced workers. Journal of Labor Economics, 13(4): 653-677.

Parent, D. 2000. Industry-specific capital and the wage profile: Evidence from the national longitudinal survey of youth and the panel study of income dynamics. Journal of Labor Economics, 18(2): 306-323.

Parsons, D. O. 1972. Specific human capital: an application to quit rates and layoff rates. The Journal of Political Economy, 80(6): 1120-1143.

Peteraf, M. A. 1993. The cornerstones of competitive advantage: A resource-based view. Strategic Management Journal, 14: 179-191.

Peteraf, M. A., \& Barney, J. B. 2003. Unraveling the resource-based tangle. Managerial and Decision Economics, 24(4): 309.

Ployhart, R. E., \& Moliterno, T. P. 2011. Emergence of the human capital resource: A multilevel model. Academy of Management Review, 36(1), 127:150.

Ployhart, R. E., Van Iddekinge, C., \& MacKenzie, W. I. 2011. Acquiring and developing human capital for sustained competitive advantage: The interconnectedness of generic and specific human capital resources. Academy of Management Journal, 54(2): 353-368. 
Ployhart, R. E., Weekley, J. A., \& Baughman, K. 2006. The structure and function of human capital emergence: A multilevel examination of the attraction-selection-attrition model. Academy of Management Journal, 49(4): 661.

Ployhart, R. E., Weekley, J. A., \& Ramsey, J. 2009. The consequences of human resource stocks and flows: A longitudinal examination of unit service orientation and unit effectiveness. The Academy of Management Journal, 52(5): 996-1015.

Reed, R., \& DeFillippi, R. J. 1990. Casual ambiguity, barriers to imitation, and sustainable competitive advantage. Academy of Management Review, 15(1): 88.

Rider, C., Negro, G., \& Roberts, P. 2011. Organizational failure, educational prestige, and the diminution of cumulated career advantages. Working Manuscript.

Rosenkopf, L., \& Almeida, P. 2003. Overcoming local search through alliances and mobility. Management Science, 49: 751-766.

Rousseau, D. M. 2005. I-deals: Idiosyncratic deals employees bargain for themselves.

Rousseau, D. M., Ho, V. T., \& Greenberg, J. 2006. I-deals: Idiosyncratic terms in employment relationships. The Academy of Management Review, 31(4): 977-994.

Rumelt, R. P. 1984. Towards a strategic theory of the firm. Competitive Strategic Management: 556-570, Englewood Cliffs, NJ: Prentice-Hall.

Shaw, J. D., Duffy, M. K., Johnson, J. L., \& Lockhart, D. E. 2005. Turnover, social capital losses, and performance. Academy of Management Journal, 48(4): 594. 
Somaya, D., Williamson, I. O., \& Lorinkova, N. 2008. Gone but not lost: The different performance impacts of employee mobility between cooperators versus competitors. The Academy of Management Journal, 51(5): 936-953.

Spence, M. 1973. Job market signaling. The Quarterly Journal of Economics, 87(3): 355-374.

Starbuck, W. H. 1993. Keeping a butterfly and an elephant in a house of cards: The elements of exceptional success Journal of Management Studies, 30(6): 885-921.

Stevenson, B. 2009. The internet and job search. Labor Market Intermediation, University of Chicago Press.

Teece, D. J. 1986. Profiting from technological innovation: Implications for integration, collaboration, licensing and public policy. Research policy, 15(6): 285-305.

Wang, H. C., He, J., \& Mahoney, J. 2009. Firm-specific knowledge resources and competitive advantage: The roles of economic- and relationship-based employee governance mechanisms. Strategic Management Journal, 30(12): 1265-1285.

Williamson, O. 1975. Markets and hierarchies, analysis and antitrust implications.

Williamson, O. 1988. The logic of economic organization. Journal of Law, Economics, \& Organization, 4(1): 65-93.

Wright, P. M., Dunford, B. B., \& Snell, S. A. 2001. Human resources and the resource based view of the firm. Journal of Management, 27(6): 701.

Wright, P. M., Gardner, T. M., \& Moynihan, L. M. 2003. The impact of HR practices on the performance of business units. Human Resource Management Journal, 13(3): 21-36. 
Wright, P. M., Gardner, T. M., Moynihan, L. M., \& Allen, M. R. 2005. The relationship between hr practices and firm performance: examining causal order. Personnel Psychology, 58(2): 409-446.

Wright, P. M., McMahan, G. C., \& McWilliams, A. 1994. Human resources and sustained competitive advantage: A resource-based perspective. The International Journal of Human Resource Management, 5(2): 301-326.

Zenger, T. R. 1992. Why do employers only reward extreme performance? Examining the relationships among performance, pay, and turnover. Administrative Science Quarterly, 37(2): 198-219. 
FIGURE 1

Decoupling Exchange Value and Firm-Specificity of Worker Skill Portfolios*

\begin{tabular}{|c|c|c|}
\hline \multirow{2}{*}{$\begin{array}{l}\text { Demand- } \\
\text { Side } \\
\text { Mobility } \\
\text { Constraint } \\
\text { s }\end{array}$} & \multicolumn{2}{|c|}{ Firm-Specificity } \\
\hline & $\begin{array}{c}\text { High Specificity } \\
\text { (low transferability) }\end{array}$ & $\begin{array}{c}\text { Low Specificity } \\
\text { (high transferability) }\end{array}$ \\
\hline $\begin{array}{c}\text { High } \\
\text { Constraint } \\
\text { (low } \\
\text { exchange } \\
\text { value } \\
\text { constrains } \\
\text { worker } \\
\text { mobility) }\end{array}$ & $\begin{array}{l}\text { Traditional firm-specific human } \\
\text { capital: worker skill portfolio is not } \\
\text { applicable elsewhere and the market } \\
\text { correctly values the portfolio. } \\
\text { Examples: } \\
\text { - Experienced research scientist } \\
\text { whose career focuses on a narrow } \\
\text { proprietary product line. } \\
\text { - Professor who invests in skills (like } \\
\text { case writing) that are not valued at } \\
\text { other institutions. }\end{array}$ & $\begin{array}{l}\text { Undervalued general human capital: } \\
\text { worker skill portfolio is applicable } \\
\text { elsewhere, but the market } \\
\text { underestimates the value of the } \\
\text { portfolio. } \\
\text { Examples: } \\
\text { - Research scientist with substantial } \\
\text { industry experience working for a } \\
\text { firm that is not well known in the } \\
\text { market. } \\
\text { - Experienced lawyer looking for a job } \\
\text { after stigmatized collapse of previous } \\
\text { law firm (Rider et al., 2011). } \\
\text { - Worker with idiosyncratic portfolio } \\
\text { of general human capital. }\end{array}$ \\
\hline $\begin{array}{l}\text { Low } \\
\text { Constraint } \\
\text { (high } \\
\text { exchange } \\
\text { value } \\
\text { enhances } \\
\text { worker } \\
\text { mobility) }\end{array}$ & $\begin{array}{l}\text { Overvalued firm-specific human } \\
\text { capital: worker skill portfolio is not } \\
\text { applicable elsewhere but the market } \\
\text { overestimates the portfolio's value. } \\
\text { Examples: } \\
\text { - Business school dean who is highly } \\
\text { successful at fund raising due to } \\
\text { non-transferrable (and non- } \\
\text { observable) skills. } \\
\text { - Star analyst whose performance is } \\
\text { driven by firm-specific factors } \\
\text { rather than superior general skills } \\
\text { (Groysberg, Lee, \& Nanda, 2008). }\end{array}$ & $\begin{array}{l}\text { Traditional general human capital: } \\
\text { worker skill portfolio is valuable and } \\
\text { applicable elsewhere and the market } \\
\text { correctly values the portfolio. } \\
\text { Examples: } \\
\text { - Experienced software developer who } \\
\text { worked alone on high-profile } \\
\text { projects. } \\
\text { - Experienced lawyer with established } \\
\text { record of litigation success. } \\
\text { - Professor with a strong publication } \\
\text { record in top tier journals. } \\
\text { - Business school dean who is highly } \\
\text { successful at fundraising due to } \\
\text { personality, charisma and } \\
\text { intelligence. }\end{array}$ \\
\hline
\end{tabular}

*The shaded cells identify contexts that have not been emphasized in the prior literature since it has been assumed that markets value firm-specific and general human capital correctly. 
FIGURE 2

Human Capital-Based Competitive Advantage Framework*

\begin{tabular}{|c|c|c|c|}
\hline \multirow{2}{*}{$\begin{array}{l}\text { Demand- } \\
\text { Side } \\
\text { Mobility } \\
\text { Constraints }\end{array}$} & \multirow{2}{*}{$\begin{array}{l}\text { Supply- } \\
\text { Side } \\
\text { Mobility } \\
\text { Constraints }\end{array}$} & \multicolumn{2}{|c|}{ Firm-Specificity } \\
\hline & & $\begin{array}{l}\text { High Specificity } \\
\text { (low transferability) }\end{array}$ & $\begin{array}{c}\text { Low Specificity } \\
\text { (high transferability) }\end{array}$ \\
\hline \multirow{2}{*}{$\begin{array}{c}\text { High } \\
\text { Demand- } \\
\text { Side } \\
\text { Constraint } \\
\text { (low } \\
\text { exchange } \\
\text { value } \\
\text { constrains } \\
\text { worker } \\
\text { mobility) }\end{array}$} & $\begin{array}{c} \\
\\
\text { High } \\
\text { Supply- } \\
\text { Side } \\
\text { Constraint }\end{array}$ & $\begin{array}{l}\text { 1. Likely HC-Based Advantage } \\
\text { Conditions: } \\
\text { - Skill portfolio is very firm- } \\
\text { specific } \\
\text { - Worker wants to stay at } \\
\text { current firm } \\
\text { - Market correctly values the } \\
\text { skills } \\
\text { Result: Human capital is } \\
\text { effectively isolated in focal firm } \\
\text { because (1) workers lack } \\
\text { attractive outside options due to } \\
\text { correct market pricing AND (2) } \\
\text { workers prefer not to leave focal } \\
\text { firm. }\end{array}$ & $\begin{array}{l}\text { 2. Possible HC-Based Advantage } \\
\text { Conditions: } \\
\text { - Skill portfolio is very general } \\
\text { - Worker wants to stay at current } \\
\text { firm } \\
\text { - Market underestimates value of } \\
\text { skills } \\
\text { Result: Human capital may be } \\
\text { effectively isolated in focal firm } \\
\text { because (1) workers lack } \\
\text { attractive outside options due to } \\
\text { incorrect market pricing AND (2) } \\
\text { workers prefer not to change } \\
\text { firms. }\end{array}$ \\
\hline & $\begin{array}{c}\text { Low } \\
\text { Supply- } \\
\text { Side } \\
\text { Constraint }\end{array}$ & $\begin{array}{l}\text { 3. Uncertain HC-Based } \\
\text { Advantage } \\
\text { Conditions: } \\
\text { - Skill portfolio is very firm- } \\
\text { specific } \\
\text { - Worker does not want to stay } \\
\text { - Market correctly values the } \\
\text { skills } \\
\text { Result: Human capital is } \\
\text { effectively isolated if the lack of } \\
\text { outside options due to correct } \\
\text { market pricing are overcome by } \\
\text { worker desires to leave. }\end{array}$ & $\begin{array}{l}\text { 4. Uncertain HC-Based } \\
\text { Advantage } \\
\text { Conditions: } \\
\text { - Skill portfolio is very general } \\
\text { - Worker does not want to stay } \\
\text { - Market underestimates value of } \\
\text { skills } \\
\text { Result: Human capital is effectively } \\
\text { isolated if the lack of outside } \\
\text { options due to incorrect market } \\
\text { pricing are overcome by worker } \\
\text { desires to leave. }\end{array}$ \\
\hline
\end{tabular}




\begin{tabular}{|c|c|c|c|}
\hline \multirow{2}{*}{$\begin{array}{l}\text { Demand- } \\
\text { Side } \\
\text { Mobility } \\
\text { Constraints }\end{array}$} & \multirow{2}{*}{$\begin{array}{c}\text { Supply- } \\
\text { Side } \\
\text { Mobility } \\
\text { Constraints }\end{array}$} & \multicolumn{2}{|c|}{ Firm-Specificity } \\
\hline & & $\begin{array}{l}\text { High Specificity } \\
\text { (low transferability) }\end{array}$ & $\begin{array}{c}\text { Low Specificity } \\
\text { (high transferability) }\end{array}$ \\
\hline \multirow{2}{*}{$\begin{array}{l}\text { Low } \\
\text { Demand- } \\
\text { Side } \\
\text { Constraint } \\
\text { (high } \\
\text { exchange } \\
\text { value } \\
\text { enhances } \\
\text { worker } \\
\text { mobility) }\end{array}$} & $\begin{array}{c} \\
\text { High } \\
\text { Supply- } \\
\text { Side } \\
\text { Constraint }\end{array}$ & $\begin{array}{l}\text { 5. Uncertain HC-based } \\
\text { Advantage } \\
\text { Conditions: } \\
\text { - Skill portfolio is very firm- } \\
\text { specific } \\
\text { - Worker wants to stay at } \\
\text { current firm } \\
\text { - Market overestimates value of } \\
\text { skills } \\
\text { Result: Human capital is } \\
\text { effectively isolated if overpriced } \\
\text { high demand for human capital } \\
\text { is overcome by worker desires to } \\
\text { stay. }\end{array}$ & $\begin{array}{l}\text { 6. Uncertain HC-based } \\
\text { Advantage } \\
\text { Conditions: } \\
\text { - Skill portfolio is very general } \\
\text { - Worker wants to stay at current } \\
\text { firm } \\
\text { - Market correctly values the } \\
\text { skills } \\
\text { Result: Human capital is effectively } \\
\text { isolated if accurately priced high } \\
\text { demand for human capital is } \\
\text { overcome by worker desires to } \\
\text { stay. }\end{array}$ \\
\hline & $\begin{array}{c}\text { Low } \\
\text { Supply- } \\
\text { Side } \\
\text { Constraint } \\
\end{array}$ & $\begin{array}{l}\text { 7. Unlikely HC-based Advantage } \\
\text { Conditions: } \\
\text { - Skill portfolio is very firm- } \\
\text { specific } \\
\text { - Worker does not want to stay } \\
\text { - Market overestimates value of } \\
\text { skills } \\
\text { Result: Human capital may not be } \\
\text { effectively isolated because } \\
\text { market overprices firm-specific } \\
\text { human capital AND worker } \\
\text { wants to leave. }\end{array}$ & $\begin{array}{l}\text { 8. Unlikely HC-based Advantage } \\
\text { Conditions: } \\
\text { - Skill portfolio is very general } \\
\text { - Worker does not want to stay } \\
\text { - Market correctly values the } \\
\text { skills } \\
\text { Result: Human capital cannot be } \\
\text { effectively isolated because } \\
\text { market correctly prices the } \\
\text { general human capital AND } \\
\text { worker wants to leave. }\end{array}$ \\
\hline
\end{tabular}

*While none of the cells have been fully developed in the prior literature, the shaded cells identify contexts where the departure from extant literature is particularly significant. 
Author Biographies:

Benjamin A. Campbell is an Assistant Professor of Management at the Max M. Fisher College of Business at the Ohio State University. He received his PhD from the University of California at Berkeley. His current research focuses on the role of human capital as a source of competitive advantage in dynamic environments. (campbell_224@fisher.osu.edu)

Russell Coff is the Wisconsin Naming Partners Professor of Strategic Management at the University of Wisconsin-Madison. He received his PhD from the University of California at Los Angeles. His current research focuses mainly on the role of knowledge-based assets in creating and sustaining a competitive advantage. (다fofbus.Wisc.edu)

David Kryscynski is an Assistant Professor of Strategy at the Marriott School of Management of Brigham Young University. He received his PhD from Emory University. His current research focuses on understanding the conditions under which human capital can lead to sustained competitive advantages. (dk@byu.edu) 